\title{
Severe decline of large birds in the Northern Sahel of West Africa: a long-term assessment
}

\author{
JEAN-MARC THIOLLAY
}

\section{Summary}

The current status of most West African birds is little known and may change quickly with increasing human population pressure and agriculture, road, tourism, hunting and mining developments. Following documented declines of raptors in Sudan and the Southern Sahel zones, I compared the number of birds counted along the same eight extensive transect counts in 1971$1973(3,703 \mathrm{~km})$ and $2004(3,688 \mathrm{~km})$ in arid steppes, acacia woodlands and desert mountains of northern Mali and Niger (Adrar des Iforhas, Aïr, Ténéré). The once widespread Ostrich Struthio camelus is now extinct west of Chad. No Arabian Ardeotis arabs and Nubian Bustards Neotis nuba were seen in 2004 (216 in 1970s) nor any Rüppell's Griffon Gyps rueppellii and Lappet-faced Vultures Torgos tracheliotus (114 and 96 respectively recorded in the 1970s). From Adrar to Ténéré, just one Egyptian Vulture Neophron percnopterus was recorded in 2004 (vs 75 in 1970s), but it was still common in the oases of Kawar ( $27 \mathrm{vs} 38$ ). These data are exploratory and the current status of the species involved should be further documented. Nevertheless, they are a serious warning about the future of several taxa. Overhunting, aggravated by overgrazing and degradation of acacia woodlands are obvious causes of the collapse of Ostrich and bustards. The near-extinction of wild ungulates, intensified use of cattle, increased disturbance and poisoning of predators may have been critical in the dramatic decline of vultures. An effective hunting ban, updates on the status of threatened species, reintroduction of Ostrich, enforcement of existing nature reserves and design of a new one in northern Mali are among the most urgent steps to take if the large birds of the vast subdesert areas of West Africa are to be conserved.

\section{Introduction}

The current status of many birds in West Africa is poorly known, especially in the Sahel belt from Senegal to Chad, because of a lack of active resident ornithologists, at least in recent years. Most published information (Borrow and Demey 2001) dates back to 1960-1980 (e.g. Lamarche 1980, Giraudoux et al. 1988, Morel and Morel 1990). Therefore dramatic changes have often escaped notice, as have the serious consequences on ecosystems (though gradual and sometimes unspectacular) of the dramatic human population growth.

Large-scale changes in bird populations are now monitored in Europe (Gregory et al. 2005) and North America (Sauer et al. 2005), but in the tropics there are few quantitative data on the long-term dynamics of most species (except for some waterbirds and a few threatened taxa). Information, when available, often comes from biased impressions of visiting ornithologists who have no experience of past species abundances and who tend to focus on rich spots not representative of more widespread areas. In the remote study areas, past surveys have been rare and have lacked detail (Aïr: Villiers 1950, Fairon 1975, Newby et al. 1987; Ténéré: Heu 1961; Kawar: Fairon 
1971) or focused on particular species (Golden Eagle, Aquila chrysaetos: Goar and Rukowsky 2000, Clouet and Goar 2003, 2004; Ostrich, Struthio camelus: Ostrowski et al. 2001). There is an urgent need to reassess the current conservation status of large bird species in the vast subdesert areas that are no longer spared from the increasing and spreading human pressure.

Using extensive, 33-year-old censuses, I first documented large-scale declines in raptors in northern Cameroon (Thiollay 2001), then throughout Burkina Faso, Mali and Niger (Thiollay 2006a, b). I focus here on the even more worrying status of all large birds in the vast arid belt of northern Niger and Mali, and sub-Saharan West Africa in general, where a better conservation situation should have been expected from its remoteness, much lower human population, few roads and absence of agriculture. These preliminary data are a warning call to prompt new investigations, and to promote conservation measures and updating of the threatened bird list.

\section{Methods}

\section{Study area}

The northern half of the Sahel is the arid or semi-arid belt just south of the Sahara. It includes two mountain ranges that are northern extensions of the Sahelian zone into the southern Sahara desert, i.e. Adrar des Iforhas in northern Mali and Aïr in northern Niger. From Senegal and Mauritania to Chad, this climate and vegetation zone extends over at least $4,000 \mathrm{~km}$ from west to east and $500 \mathrm{~km}$ from south to north, i.e. $>2$ million $\mathrm{km}^{2}$, or more than a quarter of sub-Saharan West Africa. It has a very low, mostly nomadic human population, no towns apart from Gao and Agadez on its southern fringe, no cultivation apart from small gardens in a few irrigated valleys, a short irregular rainy season and sparse thorny woodlands along highly seasonal watercourses.

Aïr and Adrar des Iforhas are arid rocky mountains (granite, sandstone and basalt), culminating at 2,310 $\mathrm{m}$ (Aï), but most often below 1,000 m, with extensive stony plateaus and often wide, more sandy valleys where most of the vegetation occurs. On both sides of the mountain ranges are extensive sandy desert or subdesert steppes (Timetrin, Tamesna, Ténéré) with a few isolated trees, or wooded valley bottoms. The rainy season is short and irregular with mean annual rainfall decreasing from 150-200 $\mathrm{mm}$ in the southern parts of the study area to about $100 \mathrm{~mm}$ in central Aïr or Adrar des Iforhas and 25-50 $\mathrm{mm}$ in the northern mountain ranges and even less in the Ténéré. The sparse grass cover decreases on average from south to north and from the ephemeral rainy season (July-September) to the cold (November-January) and hot (April-June) dry season. Cenchrus, Tribulus, Cassia, Schouwia and Aerva are common grasses and herbs in the southern steppes and Panicum turgidum, Cymbopogon, Aristida, Citrullus and Stipagrostis in the drier subdesert. Sparse and patchy woodlands include large acacia trees (often $A$. raddiana) with fewer Balanites aegyptiaca and big bushes of Salvadora persica, Calotropis procera, Maerua crassifolia, Boscia senegalensis or Euphorbia.

\section{Surveys}

Eight independent transects (see Table 1 ) were censused first from late September to the end of November 1971 and 1973 (totalling 3,703 km), then in early January and 


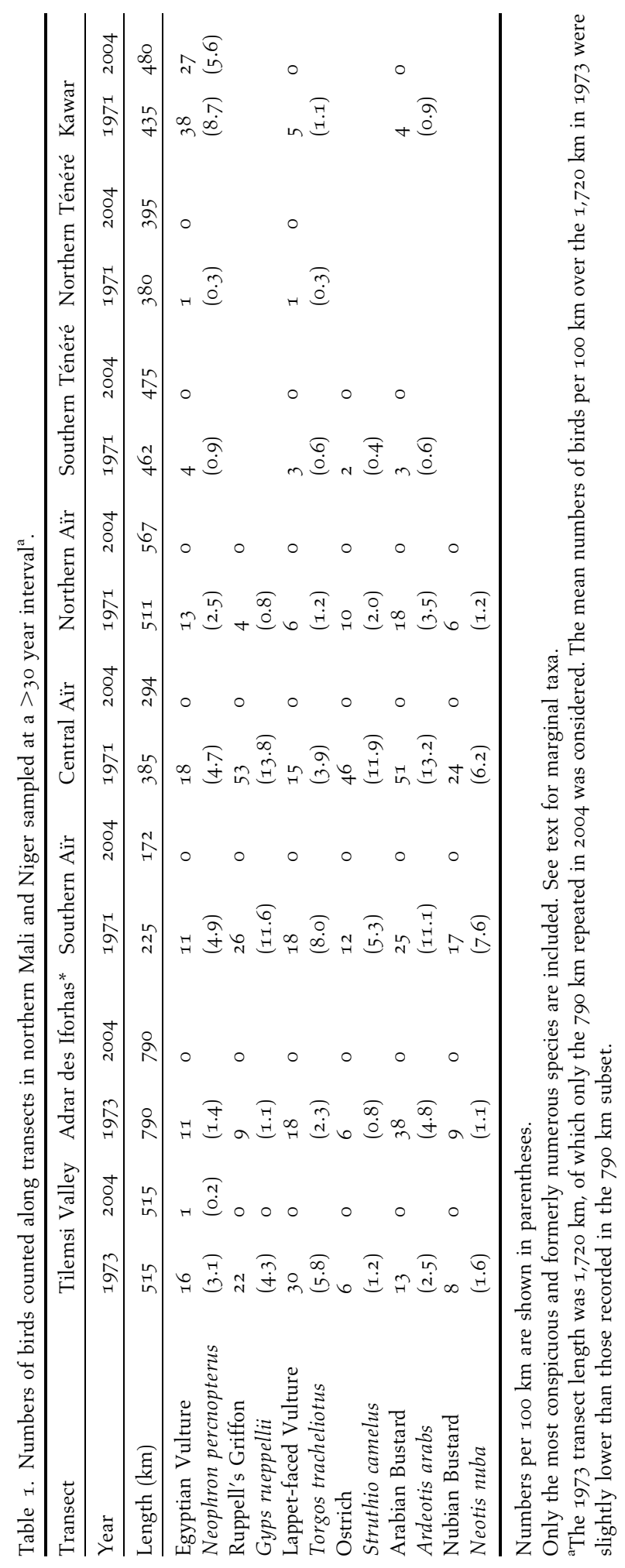


December 2004 (totalling 3,688 km). This was the early, cool dry season, after the rains and before the hot sandwinds of the later dry season (see Discussion). At the time of the surveys, grasshoppers and other large insects were extremely rare and surface water almost absent, but most trees and even a few grassy patches were still green up to January.

The surveys were divided into distinct natural areas from west to east:

1. Adrar des Iforhas (Mali), $16^{\circ} 21^{\prime}$ to $20^{\circ} 12^{\prime} \mathrm{N}$ :

(a) Tilemsi valley, just west of the mountains: flat sandy lowlands from Gao, to Tabankort, Aguelhok and Tessalit.

(b) Interior of Adrar des Iforhas (Adrar Tirarar and Adrar Ouzzeine) between Tessalit and Kidal: mid-elevation rocky mountains and narrow to wide valleys.

2. Aïr mountains (Niger), $16^{\circ} 50^{\prime}$ to $20^{\circ} 20^{\prime} \mathrm{N}$ :

(a) Southern Aïr: Assaouas-Agadez-Tiguidit-Tazolé. The most wooded area, lowlands with cliffs.

(b) Central Air: Agadez-Timia-Assodé-Iférouane. Arid plateaus, steep slopes, peaks and long valleys with irrigated gardens.

(c) Northern Aïr: Assodé-Arakao-Adrars Taghmeurt and Chirriet-Temet-Adrar Bous. North-eastern slopes of the highest mountains, foothills and sand dunes.

3. Ténéré desert (Niger), $17^{\circ} 16^{\prime}-20^{\circ} 50^{\prime} \mathrm{N}$ :

(a) Southern Ténéré: Tazolé-Arbre du Ténéré-Fachi-Bilma. Extensive sand dunes with rare patches of dry steppe and no trees (ergs of Ténéré and Bilma).

(b) Northern Ténéré, or Tafasasset: from cliffs of Dissalak to Adrar Bous through Arbre Perdu and Grein. Treeless and mostly flat sand desert.

4. Kawar: Bilma-Kirkou-Seguedine-Chirfa-Djado-Orida. Chains of isolated oases (including that of Fachi above) with palm groves and some permanent pools, along the western cliffs of the Kawar and Djado high plateaus.

The elevation of most routes was between 300 and $600 \mathrm{~m}$. The largest part of the Air and Ténéré circuit was within the 7.7 million ha Nature Reserve of Airr-Ténéré (IUCN type IV protected area and Man and Biosphere Reserve), including its central strict nature reserve (Addax sanctuary, 1.3 million ha).

\section{Bird counts}

Raptors were the primary targets. They were searched for by two observers, one of whom was always the author, in a $4 \mathrm{WD}$ vehicle, offroad or on rough tracks, along extensive routes, at low speed with frequent stops at suitable view-points, and all day long. Every individual seen perched or flying at any distance on both sides was counted even during stops, and a mean abundance index was expressed as the number of birds per $100 \mathrm{~km}$ over the full transect within each of the natural areas defined above. Some segments were covered twice in both years (Tilemsi) or in the 197os only, but in such cases only the latest count of the 1970 a and the earliest count of 2004 were used to minimize the difference between early and late surveys, as well as to make the results more comparable. The very open habitats ensured maximum detectability of most species, though, unavoidably, some birds were probably missed. 
All other large birds in addition to raptors were also recorded. The most frequent ones were not analysed, because either they were mostly seen during their morning flights to distant waterholes (sandgrouse, three Pterocles spp.), they were quite common and still not of conservation concern (crows, three Corvus spp.), or they were secretive and seen too occasionally (three owls). Ostriches were easy to see, and counts, even though they were not directed at terrestrial birds, were reliable. Conversely, bustards (Ardeotis, Neotis), though large, were sometimes inconspicuous and may have been missed when attention was focused mostly higher above the ground.

Because of very low densities of birds in these arid habitats, frequencies could be expressed only over long transects, sometimes covered over more than one day. Consequently, differences between yearly abundance values for each transect were not amenable to statistical testing, because of the small number of replicates and because often no birds were seen in 2004. However, the between-year differences do indicate population declines which merit further investigation. The relative abundances of different species are not to be compared between species because of their unequal detectability: vultures are much more visible that other raptors, and ostriches more than bustards.

\section{Results}

Ostrich Struthio camelus

Said to be abundant in Air 6o years ago (Villiers 1950), the Ostrich was still widespread and even locally quite common around 1970, although it was subjected to hunting pressure and heavy collection of eggs (pers. obs.). The 82 individuals recorded (Table I) are but a fraction of the birds seen in early surveys, and more Ostriches were recorded away from these main roads where disturbance was highest. In the 1990s, the species was on the brink of extinction in its last stronghold of the Airr-Ténéré Reserve (Ostrowski et al. 2001). None were seen in 2004, nor in extensive surveys through the Sahel of Mali, Niger and Burkina Faso in 2003 (Thiollay 2006a).

\section{Arabian and Nubian Bustards Ardeotis arabs and Neotis nuba}

Bustards were formerly one of the most characteristic elements of the north Sahelian avifauna. In the early 1970s, they were seen regularly everywhere, except in the heart of the Ténéré (Table 1). The Nubian Bustard was here less common than the larger Arabian Bustard (64 vs 152) because the Nubian was more a rainy-season migrant than the Arabian and thus would have been more widespread between $17^{\circ}$ and $20^{\circ} \mathrm{N}$, 1-3 months before the counts. In any case, not a single bustard could be seen in 2004 even though some local hunters claimed they still existed. Bustards, of course, are more easily missed during such surveys than raptors, but the sheer difference between the two censuses is indicative of a dramatic decline.

\section{Egyptian Vulture Neophron percnopterus}

Although Palaearctic migrants may also winter in northern Sahel, most of the Egyptian Vultures seen there were probably local breeders (several nest-sites were found during other surveys) and year-round residents (birds were recorded in summer 
and winter months). Egyptian Vultures were less abundant in Adrar des Iforhas than in Aïr (Table 1), and were mostly found near human settlements, wells and livestock herds. Yet, none was seen in 2004 in Aïr and Adrar. In the remote oases of Kawar (Fachi, Bilma, Dirkou), however, they remained common (up to 14 adults at a time in 2004).

\section{Rüppell's Griffon Gyps rueppellii}

Formerly common in Aïr (Villiers 1950, Heu 1961) from Tigguidit to north of Timia, Rüppell's Griffon was much less abundant in Adrar des Iforhas and absent from Kawar (Table 1). Although many cliffs still bore large splashes of white droppings accumulated in past centuries, not a single bird was seen in 2004 (nor in 2001-2004 by Clouet and Goar, unpubl. report) in spite of intensive searching. The West African population, especially in its stronghold of central Mali, has collapsed (Rondeau and Thiollay 2004) and may be severely threatened. Several birds were seen in the Gadabedji Natural Reserve, $220 \mathrm{~km}$ south of Aïr, in January 2004 (pers. obs.) and 2005 (Ph. Pilard, in litt.).

\section{Lappet-faced Vulture Torgos tracheliotus}

The Lappet-faced Vulture was the most widespread vulture in the Sahelian and desert steppes as far north as there were still some remaining acacia trees $\left(20^{\circ} \mathrm{N}\right)$. It still bred in the Gadabedji Reserve (Central Niger) in 2004, but then not a single bird was sighted along other transects where 96 had been recorded 30 years previously (Table 1). Its solitary tree-nesting habits, large, conspicuous nests and dependence on carcasses of large animals make it highly sensitive to disturbance, persecution, extinction of wild ungulates, and more intensive cattle breeding. It seems to have virtually disappeared from huge areas in West Africa and its long-term survival there is uncertain.

\section{Other raptor species}

The general picture would not be complete without a brief account of the other raptor records. These species were also carefully surveyed, even though their numbers are too low, or their appearance too seasonal, in the study area to detect significant changes in abundance between early and recent counts.

\section{Hooded Vulture Necrosyrtes monachus}

Formerly abundant in West Africa, the Hooded Vulture has declined markedly and is even locally extirpated (Rondeau and Thiollay 2004). Large numbers used to migrate in the rainy season up to southern Air and then back to the south from November onwards (Thiollay 1977). On 31 October 1971, I counted more than 300 in the town of Agadez. None was seen in early December 2004.

\section{Tawny Eagle Aquila rapax}

Formerly common in the Sudan and Sahelian zones of West Africa, the Tawny Eagle is now rare outside protected areas (Thiollay 2006a, b). It just reached the southern fringe of our study area (2 birds counted in the Tilemsi Valley in 1973, none in 2004). 
Golden Eagle Aquila chrysaetos

Discovered in early 1970s in Aïr and Adrar des Iforhas (Thiollay 1977), this southern Golden Eagle population of the Sahara mountains, though small, isolated and persecuted, has managed to survive in a surprisingly poor and arid environment (Goar and Rukowsky 2000, Clouet and Goar 2003, 2004). Their productivity, however, may be very low and no immature bird was ever seen.

\section{Verreaux's Eagle Aquila verreauxi}

On the western edge of its distribution, this rare eagle has been found only in central Aïr (Thiollay 1977) and eastern Chad (Salvan 1968). Clouet and Goar (unpubl. report) saw a pair in southeast Aïr in 2002.

Bonelli's Eagle Hieraaetus fasciatus

An adult Bonelli's Eagle was well seen in a wooded valley of Adrar des Iforhas $(25 \mathrm{~km}$ west of Aguelhoc, $19^{\circ} 25^{\prime} \mathrm{N}$ ) in January 2004. This first record of an adult south of the Sahara of a Palaearctic species whose adults are usually sedentary, would raise the possibility that it may breed there. An immature was identified $120 \mathrm{~km}$ to the south in August 1973 (Thiollay 1977).

\section{Booted Eagle Hieraaetus pennatus}

Wintering Palaearctic migrant Booted Eagle recorded once or more every year in both Adrar des Iforhas and Aïr.

Short-toed Snake Eagle Circaetus gallicus

Nine Short-toed Snake Eagles were seen along survey routes of northern Mali and 5 in south and central Aïr in 1971-1973, but none in 2004. This wintering migrant has declined moderately in West Africa (Thiollay 2006a).

\section{Martial Eagle Polemaetus bellicosus}

I recorded three individual Martial Eagles in 1971 in south and central Aïr, where one of its favourite prey, the Helmeted Guineafowl Numida meleagris, still survived. Both species seem to have since vanished from these areas at the northern limit of their distribution. At least some Martial Eagles may have been non breeding migrants. Newby et al. (1987) mentioned it from March to September in southern Aïr.

Pallid, Montagu's and Marsh Harriers Circus macrourus, C. pygargus and C. aeruginosus

The Pallid Harrier was the most frequently recorded harrier species in northern Mali and south-central Aïr ( 1 or 2 individuals on each transect every year). Montagu's Harrier was seen only in Tilemsi in 1973 and the Marsh Harrier in Tilemsi both years 
and in Kawar in 2004. These few wandering migrants do not suggest a significant decline.

Gabar Goshawk Micronisus gabar

The Gabar Goshawk may be only a seasonal migrant at this northern limit of its range. Only 3 birds were seen in the Tilemsi and 1 in southern Air in the 1970s.

\section{Dark Chanting Goshawk Melierax metabates}

A few resident Dark Chanting Goshawks reach at least $19^{\circ} 30^{\prime} \mathrm{N}$ in Aïr and Adrar des Iforhas in well-wooded valleys. On the four transects involved, 13 adults were seen in the 1970s against 6 in 2004, suggesting a possible decline in arid habitats impoverished by overgrazing.

\section{Long-legged Buzzard Buteo rufinus}

One adult of the North African subspecies of Long-legged Buzzard, B. r. cirtensis, was seen in 1971 and 2004, around $19^{\circ} 30^{\prime} \mathrm{N}$ in both northern Adrar des Iforhas and Aïr. Up to now, all birds south of the Sahara were considered to be Palaearctic migrants. However, this buzzard is a widespread breeder in North Africa, down to the Ahaggar mountains just north of our study area (Isenmann and Moali 2000). Thus, like the Golden Eagle, the Long-legged Buzzard may be expected to breed in extreme northern Mali and Niger.

\section{Common Kestrel Falco tinnunculus}

The African subspecies of Common Kestrel, F. t. rufescens, was uncommon but widespread up to Northern Adrar des Iforhas, Aïr and Kawar in the 1970s (19 on six transects). Fewer were seen in 2004 (6 on three transects).

\section{Lanner Falcon Falco biarmicus}

The Lanner Falcon breeds between January and April, and part of the Sudano-Sahelian population moves northward during the rains, sometimes up to $20-21{ }^{\circ} \mathrm{N}$ (Thiollay 1977), especially in years where locusts are abundant. It occurs well into the desert on isolated rocky hills where it may nest, using spring migrants as main source of food (Heu 1961, Newby 1981). I saw none of them in the Ténéré desert during December counts (except on the cliffs of Dissalak on the eastern limit), but their presence at other seasons was suggested by numerous pluckings of migrants on every rocky outcrop. Lanners were less frequent in 2004 ( 17 on four transects) than in the 1970 ( 27 on six transects).

\section{Barbary Falcon Falco pelegrinoides}

Most Peregrines seen around cliffs of Adrar and Aïr mountains seemed to be resident Barbary Falcons, although breeding of this species has yet to be confirmed on the southern edge of the Sahara (Borrow and Demey 2001). There were nearly as many 
sightings in early and late years in Adrar des Iforhas (2 and 2) and south-central Aïr ( 3 and 1 ).

Other Falcons reach their extreme northern limit here: I Red-necked Falcon Falco chicquera south-east of Agadez in both years, and 2 Fox Kestrels Falco alopex near Timia (central Aïr) in June 1971 only.

\section{Discussion}

These field records are a preliminary account. The actual status of the species involved should be more thoroughly documented. However, there are no other comparative data against which to assess their past population sizes.

\section{Comparability of counts}

Most species studied are residents in the study areas. Some of them, however, may increase markedly during the short rains (July-August) and go back to the southern Sahel from September to December (Thiollay 1978). Among the species involved, Nubian Bustard, Rüppell's Griffon, Hooded Vulture and Lanner Falcon are known to perform such seasonal movements. However, it is unlikely that the slightly earlier counts of the 1970s may have included significantly more such migrants than the 2004 counts because the first counts, especially in 1973, occurred in drought years when few northward movements occurred, whereas the better 2003 and 2004 rainy seasons should have allowed a larger influx and/or a longer stay of these migrants.

Moreover, the 2004 counts covered all the previous transects on exactly the same itineraries (as far as it was possible in such roadless areas). Because the observer was the same, and the conditions and timing similar, the two series of counts can be considered to be as comparable as possible. Additionally, the species studied were large and usually conspicuous in such very open habitats. Their absence, or much lower numbers, in 2004 must have been highly significant, even if it did not mean a complete extinction.

\section{Environmental changes in the last decades}

Highly publicized droughts in the Sahel have led to the general belief that observed desertification was the inevitable result of climate change. In fact, after the serious drought of 1973, rainfall has fluctuated, but both cattle and people have recovered (pers. obs.). The strong human population growth that is affecting West Africa is still not so conspicuous in the study areas, except for the rapid growth of the few towns and the development of mining (locally) and tourism (in remote areas). Otherwise, slow but continued desertification is mostly the result of an unsustainable human pressure, even though a low population density and traditional nomadic lifestyle still prevail. Degradation and thinning of sparse and non-regenerating acacia woodlands, overgrazing of subdesert steppes and excessive removal of firewood are followed by wind erosion and sand encroachment. Improved human and veterinary medicine, increasing offroad vehicle traffic and systematic chemical treatments against locusts also probably contribute to a general impoverishment of natural ecosystems. 


\section{Collapse of the large fauna}

Even more obvious and significant than the demise of the avifauna is that of the larger wild mammals. Local people already admitted it in the 196os, but it has now become a near extinction. The most widespread and typical ungulate, the Dorcas Gazelle Gazella dorcas, was then killed annually by the hundreds along survey transects. In 19711973, I counted 628 of them, against only 13 in 2004. The Dama Gazelle Gazella dama (only 25 counted in 1970s) and the Addax Addax nasomaculatus ( 5 seen) were already severely depleted, but none were recorded in 2004. The Scimitar-horned Oryx Oryx dammah was probably already extinct 30 years ago. The Barbary Sheep Ammotragus lervia, difficult to see on the rocky slopes, still survives but was not seen along the 2004 transects (against 12 in 1971), similarly the Patas Monkey Erythrocebus patas (1 vs 37).

Most carnivore species survive despite intense persecution with guns, traps and poison. Tracks of Jackals Canis aureus, Foxes Vulpes rueppellii, Fennecs Fennecus zerda, and even twice Striped Hyenas Hyaena hyaena were frequently encountered in 2004, but none of Sand Cat Felis margarita, Caracal Felis caracal or Cheetah Acinonyx jubatus, all of which were seen in the 1970s. Cape Hare Lepus capensis, main prey of Golden Eagles (Clouet and Goar 2003, 2004), was seen much less often in 2004 than in 1971.

Many of these large mammals, once abundant according to early twentieth-century records, are facing regional extinction and illustrate the global impoverishment and loss of biodiversity of the north Sahelian ecosystems.

\section{Overhunting}

Even if overgrazing, woodland degradation and increasing disturbance hinder the survival of large birds as well as mammals, heavy, relentless hunting pressure is likely to be the main reason for the dramatic decline or near-extinction of all large terrestrial birds (ostriches, bustards, guineafowls), according to many reports from local people, NGOs and authorities. Ostriches have long suffered from egg collection. Bustards were occasionally trapped and their broods taken by nomads. The advent of guns and cars resulted in heavy hunting by military or mining personnel, as well as tourists, who ignored hunting legislation when it existed. The organized hunting parties of wealthy Arabs have recently had a devastating effect. Widespread trapping and poisoning of jackals and hyenas by nomads may affect vultures. Nest-robbing of eagles for trade or predator destruction was frequently reported by local people.

\section{Continuing extinction of large terrestrial birds}

Even during a first survey in 1969, local people unanimously estimated that ostriches, bustards, gazelles and other ungulates had already decreased considerably compared with previous decades. All are now much rarer than in 1969.

The Ostrich was still recorded in Aïr up to 1986 (Newby et al. 1987) but may be now considered extinct west of Cameroon and Chad (Ostrowski et al. 2001). Helmeted Guineafowl, still frequent in Aïr 6o years ago (Villiers 1950), was last seen in 1971 (pers. obs.) and not mentioned by Fairon (1975) and subsequent authors. The exact decline of bustards is difficult to assess because of a lack of monitoring, and seasonal 
movements obscuring local fluctuations. Moreover long-lived birds may survive for years without breeding before dying out. The lack of records in 2004 may not (hopefully) mean that bustards are extinct, but it is indicative of a breakdown which also occurred throughout the West African Sahel (pers. obs.).

\section{Large-scale decline of vultures}

Rüppell's Griffon and Lappet-faced Vulture were numerous, at least in Aïr (Villiers 1950, Heu 1961), well into the early 1970s (Table 1) and even the 1980s (Newby et al. 1987). Their apparent extinction on the 2004 transects agrees with their massive decrease recently documented throughout the Sahelian belt of Mali and Niger south of the present study area (Rondeau and Thiollay 2004, Thiollay 2006a). M. Clouet and J. L. Goar (in litt.) saw five Lappet-faced Vultures in Aïr in 2001, but no Rüppell's Griffons. They did not see a single large vulture in Adrar des Iforhas during three surveys from 2001 to 2003 (Clouet and Goar 2003).

There is no obvious reason for such a general collapse. The current habit of poisoning carcasses to kill jackals was already practised in the 1970s, but may have been finally devastating. The dwindling wild mammals no longer provide a reliable food source for vultures. Domestic cattle, however, have not decreased but sick or dying animals are now rarely left for vultures because of an increasing economic pressure. Few veterinary medicines are used in these remote areas (such as Diclofenac involved in the decline of vultures in India; Oaks et al. 2003) and direct persecution of vultures has not been reported. A combination of lower food availability, higher nest disturbance and an increased incidence of poisoning may be responsible for the collapse of vultures.

The smaller Egyptian Vulture, living on scraps around nomad camps and oases, survived much better in the remote still traditional-living area of Kawar, while it strongly declined in Aïr and Adrar des Iforhas where human pressure and persecution may have increased.

\section{Surviving eagles and other raptors}

The collapse of their source population in the Sahel may explain the current lack of observation of Tawny and Martial Eagles in Aïr. The small isolated population of Golden Eagles, as well as the few pairs of Verreaux's Eagle, survive in this arid environment in spite of low food resources and persecution (Clouet and Goar 2004). Even some possible, but still unconfirmed breeders (Bonelli's Eagle, Short-toed Snake Eagle, Long-legged Buzzard, Barbary Falcon) have been recorded recently. Other sparse and local breeding raptors (Chanting Goshawk, Lanner Falcon, Common Kestrel) also maintain precariously low populations. Palaearctic migrants (Short-toed Snake Eagle, Booted Eagle, harriers) still stop, even if they do not winter, in the richest patches. The few records available cannot suggest that these species have actually decreased.

\section{Monitoring and conservation}

Of all resident birds listed here, only the Lappet-faced Vulture is in the Threatened category (Vulnerable) of the IUCN Red List (BirdLife International 200o) and the 
Nubian Bustard is Near-Threatened. Such conservative status and the unlisted potential candidates are based on old records, poor information, no recent assessment of a rapidly changing situation, and also on their wide distribution and supposedly better conservation status in East Africa (though this remains little documented outside protected areas).

The West African subspecies of the Ostrich, S. c. camelus, is now critically endangered in the wild. The large vultures are currently found in very small numbers at widely separated localities, at least from Mali to Cameroon, pending surveys in other countries. The large bustards (Neotis, Ardeotis) have been severely overhunted and may have become extinct over huge areas. They all deserve a Threatened status.

From Mauritania to Chad, in the northern Sahel, there are only two theoretically protected areas: the Aïr-Ténéré Natural Reserve in Niger $\left(77,000 \mathrm{~km}^{2}\right)$ and the Ouadi Rimé-Ouadi Achim Faunal Reserve in Chad $\left(80,000 \mathrm{~km}^{2}\right)$. Together they cover about $7 \%$ of the area involved, but both are inhabited and totally devoid of any management or law enforcement. A stronger and effective conservation status of these reserves would be essential, though probably not enough to maintain large bird populations with very low natural densities and extensive seasonal movements.

Strictly enforced hunting legislation is crucial to save bustard populations. The Ostrich has to be reintroduced in Niger and Mali (a recent IUCN project in Niger has failed). There is also an obvious lack of a large reserve in northern Mali, as a counterpart for those in Niger and Chad. The almost complete disappearance of large fauna, the persistent insecurity, if not warfare, and the huge remote areas to be patrolled, do not encourage such projects, but they are important prerequisites if the unique Sahelian and sub-Saharan fauna is to be saved.

\section{Acknowledgements}

The study was funded by IRD (Institut de Recherches pour le Développement) under UR 136 Project "Functions and management of protected areas in West Africa" (Supervisor : Anne Founier). M. Clouet, J. L. Goar, M. Terrasse and F. Thiollay participated in the 2004 surveys, as did more than 10 other guides and colleagues in earlier surveys. Without them all, expeditions in those remote areas would have been more difficult and expensive and their help was essential.

\section{References}

BirdLife International (2000) Threatened birds of the world. Cambridge, UK: BirdLife International.

Borrow, N. and Demey, R. (2001) Birds of western Africa. London: Christopher Helm.

Clouet, M. and Goar, J. L. (2003) L'avifaune de l'Adrar Tirharhar/Adrar des Iforhas (Mali). Alauda 71: 469-474.

Clouet, M. and Goar, J. L. (2004) L'Aigle royal, Aquila chrysaetos, au Niger. Alauda 72: 151-152.

Fairon, J. (1971) Exploration ornithologique au Kaouar (hiver 1970). Gerfaut 61: 146-161.

Fairon, J. (1975) Contribution à l'ornithologie de l'Aïr (Niger). Gerfaut 65: 107-134.

Giraudoux, P., Degauquier, R., Jones, P. J., Weigel, J. and Isenmann, P. (1988) Avifaune du Niger: état des connaissances en 1986. Malimbus 10: 1-140.

Goar, J. L. and Rukowsky, T. (2000) Reproduction de l'Aigle royal, Aquila chrysaetos, au Mali. Alauda 69: 327-328. 
Gregory, R. D., van Strien, A. J., Vorisek, P., Meyling, A. W., Nobel, D. G., Foppen, R. P. B. and Gibbons, D. W. (2005) Developing indicators for European birds. Phil. Trans. R. Soc. Lond. Ser. B 360: 269-288.

Heu, R. (1961) Observations ornithologiques au Ténéré. Oiseau et RFO 31: 214-239.

Isenmann, P. and Moali, A. (200o) Oiseaux d'Algérie. Paris: SEOF.

Lamarche, B. (1980) Liste commentée des oiseaux du Mali. Malimbus 2: 121-158.

Morel, G. J. and Morel, M. Y. (1990) Les oiseaux de Sénégambie. Paris: ORSTOM.

Newby, J. E. (1981) Notes on the Lanner (Falco biarmicus) from Ténéré desert, with comments on the incidence of scorpion predation by raptors. Malimbus 3: 53 .

Newby, J., Grettenberger, J. and Watkins, J. (1987) The birds of Northern Air, Niger. Malimbus 9: 4-16.

Oaks, J. L., Gilbert, M., Virani, M. Z., Watson, R. T., Meteyer, C. U., Rideout, D. A., Shivaprasat, H. L., Ahmesd, S., Chaudhry, M. J., Arshard, M., Mahmood, S., Ali, A. and Khan, A. A. (2003) Diclofenac residues as the cause of vulture population decline in Pakistan. Nature 427: 630-634.

Ostrowski, S., Massalatchi, M. S. and Mamane, M. (2001) Evidence of a dramatic decline of the Red-necked Ostrich, Struthio camelus in the Aïr and Ténéré National Nature Reserve, Niger. Oryx 35: 349-352.

Rondeau, G. and Thiollay, J. M. (2004) West African vulture decline. Vulture News 51: 13-33.

Salvan, J. (1968) Contribution à l'étude des oiseaux du Tchad. Oiseau et RFO 38: 53-85.

Sauer, J. R., Hines, J. E. and Fallow, J. (2005) The North American breeding bird survey. Results and analysis 1966-2004. Version 2005. Laurel, MD: USGS Patuxent Wildlife Research Center.

Thiollay, J. M. (1977) Distribution saisonnière des rapaces diurnes en Afrique Occidentale. Oiseau et RFO 47: 253-294.

Thiollay, J. M. (1978) Les migrations de rapaces en Afrique Occidentale: adaptations écologiques aux fluctuations de production des écosystèmes. Terre et Vie 32: 89-133.

Thiollay, J. M. (2001) Long-term changes of raptor populations in Northern Cameroon. J. Raptor Res. 35: 173-186.

Thiollay, J. M. (2006a) The decline of raptors in West Africa: long-term assessment and the role of protected areas. Ibis 148: 240-254.

Thiollay, J. M. (2006b) Large bird declines with increasing human pressure in savana woodlands (Burkina Faso). Biodiv. Conserv. 15: 2085-2108.

Villiers, A. (1950) Contribution à l'étude de l'Aïr. Oiseaux. Mém. IFAN ıo: 345-385.

JEAN-MARC THIOLLAY

CERSP, CRBPO, Museum National d'Histoire Naturelle, UMR 5173, 55 rue Buffon 75005 Paris, France. E-mail:jm.thiollay@wanadoo.fr

Received 3 May 2005; revision accepted 23 February 2006 